\title{
ROBINSON CRUSOESTA AKTIIVISEEN AIKUISOPISKELIJAAN
}

\section{Fifth international symposium on adult self-directed learning}

Viides kansainvälinen itseohjattua opiskelua käsittelevä symposiumi pidettiin USA:ssa Oklahomassa helmikuun lopulla. Kansainvälisyys jäi kiristyneen maailmantilanteen vuoksi vähiin, sillä suurin osa ulkomaisista osanottajista oli peruuttanut tulonsa. Kansainvälisyys jäi yhden eteläkorealaisen, yhden malesialaisen ja yhden suomalaisen varaan. Isäntämaan ja Kanadan edustajia sen sijaan oli paikalla sitäkin nimekkäämpi joukko: Malcolm Knowles, Huey Long, Rosemary Caffarella, Claudia Danis, Lucy M. Guglielmino, Roger Hiemstra, Gary Confessore, Carol Kasworm, Lloyd Korhonen ...

Yritän seuraavassa kuvata lukijoille niitä teemoja, jotka tuntuivat symposiumin annin pohjalta ajankohtasilta tällä alueella. Aikuisten itseohjattu opiskelu (tai mitä termiä nyt sitten halutaankin käyttää: Tässä käytetään nimenomaan käsitteitä "'itseohjattu opiskelu" ja "'itseohjautuva opiskelu". Itseohjautuvuus nähdään opiskelijan ominaisuutena, kun taas opiskelu voi olla itseohjattua, mutta ei "'itseohjautuvaa". - vrt. kuitenkin Varila 1990.) on USA:ssa ollut pinnalla jo toistakymmentä vuotta, ja Suomikin seuraa perässä hyvää vauhtia. Mitä tuo käsite sitten pitää sisällään ? Ja mikä on aihetta koskevan tutkimuksen nykytila?

\section{Mitä se on?}

Käsitteellinen epäselvyys ja monimuotoisuus on yksi itseohjatun opiskelun ja siihen kohdistuvan tutkimuksen ongelmista - ja rikkauksista. Symposiumin ohjelmaan oli sijoitettu liki kolmituntinen aivoriihityöskentely. Teoriaa, käsitettä ja määritelmää pohtiva ryhmä tuotti ensimmäisen puolen tunnin aikana kuusi fläppitaulun lehteä käsittävän listan erilaisia määritelmiä käsitteelle "'self-directed learning". Kun ryhmä vielä huomasi, että määritelmät voidaan jakaa didaktisia, psykologisia, sosiologisia, poliittisia, filosofisia ja jopa taloudellisia aspekteja painottaviin teemoihin, luovuttiin käsitteen määrittelystä ja siirryttiin puhumaan sen käytön oikeutuksesta.
Tarve käsitteen määrittelyyn ja ilmiön rajaamiseen on kuitenkin tiedostettu, ja esityksissäkin oli joitakin piristäviä poikkeuksia tähän suuntaan. Käsitteen suunnasta ongelmaa lähestyi Lorraine S. Gerstner, joka oli tutkinut käsitteen käyttöä ja sen erilaisia merkityksiä. Gerstnerin esityksen yksi pääteema oli, että käsitteellä "'selfdirected learning" voidaan viitata useaan eri ilmiöön:

- opiskelutilanteiden suunnitteluun ja hallintaan

- opiskelutaitojen kehittämiseen

- tietoisuuden (consciousness) muutokseen

- tietoisuuden (awareness) tilaan

- valinnanvapauteen

— omien arvojen toteuttamiseen

- sisäiseen kehitysprosessiin

Ilmiön kautta tapahtuva käsitteen selkiyttäminen lienee hedelmällisempi lähestymistapa. Kahdessa esityksessä pyrittiin selvittämään, mitä aikuisten opiskelu todella on ja miten itseohjattu opiskelu siihen suhteutuu (Danis, Kasworm). Kanadalainen Claudia Danis esitteli tutkimushankettaan, jossa pyrittiin rakentamaan viitekehys itsesäädeltyjen opiskeluprosessien (self-regulated learning processes) analyysia varten. Kunnianhimoinen hanke, jolta voinee odottaa paljon; nimi kannattaa pitää mielessä.

Carol Kasworm esitteli Grounded Theory -lähestymistavalla tehtyä haastattelututkimustaan, jossa oli pyritty selvittämään aikuisopiskelijoiden orientoitumista yliopisto-opintoihin. Kaswormin mukaan myös formaalissa opiskeluympäristössä esiintyy itseohjautuvuutta, ja monilla aikuisilla formaali opiskelutilanne on tietoinen valinta tehokkaan opiskelun turvaamiseksi. Kaswormin alustava analyysi oli sikälikin mielenkiintoinen, että se auttaa ymmärtämään erilaisia opiskeluorientaatioita, joita yhä kasvavalla aikuisiällä yliopistossa opiskelevien joukolla voi olla.

Symposiumissa käsitteen määrittely jäi vielä tekemättä, eikä halua tai tarvettakaan sen mää- 
rittelemiseksi tuntunut juuri olevan. Itseohjattu opiskelu nähtiin lähinnä viitekehyksenä, jonka puitteissa voidaan tehdä erilaista tutkimus- ja kehittämistyötä. Carol Kasworm määritteli sen ajattelu- ja puhetavaksi, eikä käsitteelle siten ole mahdollista löytää yhtä määritelmää. Tosin samaan hengenvetoon hän nosti itseohjatun opiskelun yhdeksi oppimisteoriaksi. Lucy M. Guglielmino puolestaan oli vakuuttunut, että kyseessä on tärkeä alue, joka mullistaa oppimiskäsityksen.

Itseohjatun opiskelun ilmiön ja käsitteen laajentumisesta antaa hyvän esimerkin se, että ensimmäiset symposiumit keskittyivät yksinäiseen, eräänlaiseen Robinson Crusoe -tyyppiseen opiskelijaan, kun taas tämän viidennen symposiumin keskeinen teema oli itseohjautuva aikuisopiskelija sosiaalisessa kontekstissa (ryhmäopiskelutilanteissa, luokassa ja työssä).

Ilmiön jäsentymistä odotellessa on syytä meidän suomalaistenkin muistaa Huey Longin ohje: kaikki sanat ovat sanakirjassa, älä keksi uusia, vaan käytä niitä.

\section{Knowles}

Seminaarin avausistuntoon oli kutsuttu Malcolm Knowles "'asettamaan alkutahdit". Vaikka andragogiaa voikin monilta osin kritisoida (esimerkiksi Manninen \& al. 1988), ei liene epäilystä siitä, etteikö juuri Malcolm Knowles olisi yksi aikuiskoulutuksen merkkihahmoista. Harmaantuneen mutta henkisen vireytensä säilyttäneen auktoriteetin tapaaminen oli nuoren jatko-opiskelijan kannalta merkittävä tapahtuma.

Knowlesin tunnin pituinen sessio oli hyvin andragoginen. Alku kului kolmen hengen ryhmissä, kun osallistujat selvittivät toisilleen odotuksiaan symposiumin suhteen. Puoli tuntia kului 'ryhmätöiden' purkamiseen. Kun eräs kuulijoista vihdoin sanoi, ettei ole kuullut koskaan Knowlesin itsensä puhuvan, saatiin lopulta kuulla Knowlesin omia ajatuksia. Knowlesin mukaan itseohjattu opiskelu on geneettistä ja luonnollista alle viiden vanhalla lapsella, kunnes koulu tuon ominaisuuden tappaa. Itseohjattua opiskelua Knowlesin mukaan on se, jossa opiskelija tekee aloitteen (initiative). Lopuksi Knowles määritteli kolme tekijää, jotka asettavat vaatimuksia aikuisten itseohjatun opiskelun kehittämiselle, nimittäin demografiset muutokset, muutosten nopeutuminen ja tekniikan kehitys (etäopetusmenetelmät).

Knowlesin esittämät ajatukset ovat tosin luettavissa jo hänen kymmenen vuotta sitten ilmes- tyneistä kirjoistaan. Knowlesin kontribuutio itseohjatun opiskelun alueella tuntuukin keskittyvän siihen alkusysäykseen, jonka andragoginen ajattelu on aikuiskoulutukselle antanut.

\section{Trendit}

Symposiumin esityksissä oli havaittavissa tiettyjä aihekokonaisuuksia. Valtaosa esityksistä keskittyi viitekehyksen puitteissa tehtyihin opiskelututkimuksiin, joissa oli etsitty yhteyksiä opintotai työmenestyksen ja itseohjatun opiskelun valmiuksien välillä (esimerkiksi McCune \& al., Price $\&$ al., York). Toinen keskeinen teema oli SDLRSmittariin liittyvät validointiyritykset (esimerkiksi Jones), ja kolmas edellä mainitut käsitteen ja ilmiön selkeyttämiseen tähtäävät tutkimukset (Kasworm, Gerstner, Danis). Varsin uusi sovellusalue tuntui olevan etäopetus ja siihen liittyvä itseohjattu opiskelu (Titsworth \& al., Manninen sekä esittämättä jäänyt nigerialaisen Adekanmbin paperi).

Oman mielenkiintoisen kokonaisuuden muodostivat itseohjautuvuuteen liittyvää tutkimusta ja sen tuloksia analysoivat esitykset (Caffarella, Hiemstra, Confessore \& Confessore). Viimeksi mainitussa oli delfi-tekniikalla selvitetty alan asiantuntijoiden käsityksiä tärkeistä tutkimustuloksista, keskeisistä tutkimusaiheista, lähestymistavan annista aikuiskasvatuksen teorialle ja käytännölle sekä alueen tärkeimmistä julkaisuista.

Confessorien selvityksen mukaan asiantuntijat - amerikkalaiset — ovat yksimielisiä ainakin seuraavista trendeistä:

Tärkeimpiä tutkimustuloksia:

- Tough'in tutkimukset

- itseohjattu opiskelu ei ole lineaarinen, askel askeleelta etenevä prosessi

— ympäristön osuus on tärkeä

- itseohjautuva opiskelu ei tapahdu eristyksissä muista, vaan opiskelija käyttää useita resursseja ja henkilöitä oppiessaan

- kouluttaja voi edistää itseohjautuvuutta omilla toimillaan.

\section{Tärkeimpiä tutkimusalueita:}

— käsitemallin rakentaminen

- opiskelijan, ympäristön ja opetus-oppimistilanteen ominaisuuksien ja itseohjatun opiskelun vuorovaikutus, mielellään erilaisten psykologisten teorioiden näkökulmasta

- itseohjautuvuuteen liittyvien persoonallisuuspiirteiden etsintä

— yksilölliset erot

- miten voidaan edistää opettajan/ympäristön toimesta

- kvalitatiiviset tutkimukset 
— miten opiskelustrategiat ja työssä menestyminen liittyvä toisiinsa

Tärkeimpiä vaikutuksia teoriaan:

— oppija asetettu keskeisempään asemaan

- formaalien oppimistilanteiden ulkopuolella tapahtuvan oppimisen ymmärtäminen

Keskeisintä kirjallisuutta selvityksen mukaan ovat Brookfieldin, Houlen sekä Toughin teokset.

Selvityksen mukaan Guglielminon SDLRSmittari tuntuisi olevan valmiiksi asti käsitelty, mutta kuten esimerkiksi Adult Education Quarterly -lehden numero 2/91 osoittaa, ei keskustelu tästä mittarista ole vielä päättynyt. Koska kyseinen mittari tuntui olevan hyvin keskeisessä asemassa amerikkalaisessa tutkimuksessa - ja itse asiassa ilmiön lähes ainoa empiirinen mitta olisi syytä edelleen arvioida kriittisesti ko. mittarin soveltuvuutta. Lucy M. Guglielmino muuten sai symposiumissa plakaatin tunnustuksena "'merkittävästä kontribuutiosta itseohjatun opiskelun tutkimuksen alueella".

\section{Kontribuutio?}

Symposiumin jälkeen jäi paljolti sellainen vaikutelma, että self-directed learning on hyvin pitkälle pelkkä viitekehys, jonka puitteissa on mukava tehdä aikuisten oppimiseen liittyvää tutkimusta, ja joka lisäksi myy hyvin. Humanistisen psykologian myötä koulutusteknologista mallia kohtaan esitetystä kritiikistä ei olisi voinut olla muutakaan seurausta kuin painopisteen siirtyminen opettamisesta oppimiseen. Ainakin tällä hetkellä tuntuu täysin luonnolliselta, että aikuiset nähdään aktiivisina, omasta oppimisestaan vastuuta kantavina yksilöinä.
Varsinkin etäopetuksen ja monimuoto-opiskelun yleistyessä syntyy yhä enemmän tarvetta korostaa aikuisten itseohjautuvuutta ja omatoimista opiskelua. Tällöin on tietenkin vaarana, että kaikki vastuu siirtyy opettajalta opiskelijalle, ja oppija jätetään oman onnensa ja itseohjautuvuutensa varaan.

Mitä sitten on pohjoisamerikkalaisen itseohjattua opiskelua koskevan tutkimuksen anti suomalaiselle aikuiskasvatukselle? Tällä hetkellä tuntuisi, että anti voisi olla vastavuoroinen, ellei peräti vientivoittoinen. Esimerkiksi itseohjautuvan työryhmän/laatupiirin käsite (Sarala 1988) oli vielä täysin tuntematon ja herätti lähinnä hilpeyttä. Kehittävä työntutkimus ja siihen liittyvä ajattelutapa pohjautuu nimenomaan "'itseohjautuviin työn kehittäjiin"'. Käsitteellisellä puolella meiltä löytyy varmasti kansainvälisille markkinoille kelpaavaa tutkimusta. Myös erilaiset näkökulmat oppimiseen kuten toiminnan teoria (Engeström 1986) ja muutosorientoitunut, reflektiivisyyttä painottava koulutussuunnittelu (Kontiainen \& Manninen 1991) saattaisivat hyvinkin tuoda jotain uutta itseohjautuvuuden alueelle.

Varsin silmiinpistävänä symposiumissa tuli esille kvalitatiivisen tutkimuksen puute ja tarve. Ainoa kvalitatiivisella otteella toteutettu tutkimus on Kaswormin analyysi yliopisto-opiskelijoista. Suomalaisissa yliopistoissa kvalitatiivinen tutkimus tuntuu tällä hetkellä olevan melko vahvoilla, ja tälle alueelle kannattaisi ehkä panostaa.

Kuudes symposiumi pidetään 1992 tammikuussa West Palm Beachilla Floridassa ...

\section{JYRI MANNINEN}

\section{LÄHTEET}

Engeström Yrjö 1986. Learning by expanding. Helsinki: Orientakonsultit.

Kontiainen Seppo \& Manninen Jyri 1991. A framework for adult education. Forskning i Norden, Nordiska symposium om forskning inom folkutbildning och vuxenutbildning, Göteborg 9.-11.6.1991.

Manninen, J. \& Kauppi, A \& Kontiainen, S. 1988. Koulutussuunnittelun lähtökohtia. Analyysi Knowlesin andragogiikasta didaktisena lähestymistapana. Helsingin yliopisto, Kasvatustieteen laitos, tutkimuksia 116.
Sarala Urpo 1988. Kohti oppivaa organisaatiota. Helsingin yliopisto, Lahden tutkimus- ja koulutuskeskus.

Varila Juha 1990. Itseohjautuvan oppimisen käsitteellistä ja empiiristä tarkastelua. Helsingin yliopisto, Lahden tutkimus- ja koulutuskeskus. Tutkimuksia no. 2.

Tekstissä mainittuja esityksiä voi tiedustella Jyri Manniselta, Kasvatustieteen laitos, Helsingin yliopisto, puh. 90-1918063 tai 911-33718. 